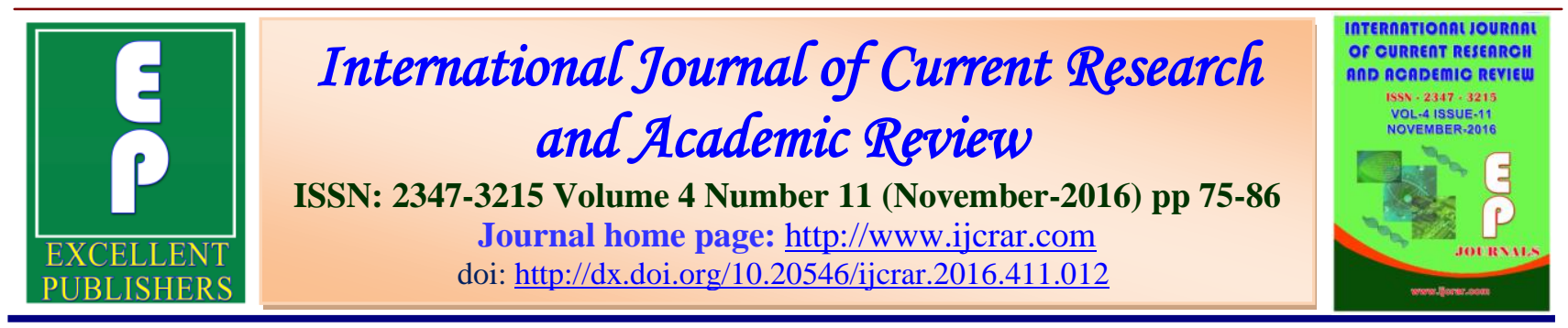

\title{
Impact of TQM Practices on Operational Performance of Firms in India - An Empirical Study
}

\author{
Vasantharayalu*
}

PhD Research Scholar - BITS Pilani, India

*Corresponding author

\begin{tabular}{|l|l|}
\hline KEYWORDS & A B S T R A C T \\
$\begin{array}{l}\text { Operational } \\
\text { Performance, Service } \\
\text { and Manufacturing } \\
\text { Sector, } \\
\text { TQM Practices. }\end{array}$ & $\begin{array}{l}\text { The present paper empirically tested the relation of TQM practices on } \\
\text { operational performance in both service and manufacturing industries. Hence } \\
\text { the study used } 300 \text { participants from } 50 \text { service and manufacturing industries } \\
\text { in India. The data was collected from respondents by using survey method. } \\
\text { The questionnaire was designed on the relation of TQM practices on } \\
\text { operational performance. Questionnaire covers the following TQM factors } \\
\text { namely leadership, process management, employee management, continuous } \\
\text { improvement, and customer focus. These questionnaires were shared to } 300 \\
\text { respondents and the collected data was tested by using various tests such as } \\
\text { frequency tests, descriptive, SEM analysis, correlation, multiple regression } \\
\text { analysis tests etc. The study results found that the operational performance } \\
\text { views Leadership, Strategic and Planning, Customer Focus, Information and } \\
\text { Analysis, People Management and Quality Performance are statistically } \\
\text { significant in both kinds of industries. Hence the application of TQM } \\
\text { practices in both service and manufacturing industries is necessary to } \\
\text { maintain the quality of the work as well as enhance the competition level in }\end{array}$ \\
\hline
\end{tabular}

\section{Introduction}

Globally, leaders or managers in different organizations obtain satisfaction from satisfying the needs of customers which is the central philosophy of Total Quality Management (TQM) practices. TQM is a holistic approach for quality improvement in operational performance of organisation was a serious debate among various researchers and policy makers. Organisations, in general adopted TQM practices for ensuring the organisation's entire operations to achieve competitive advantage. According to Lee et al., (2013)as the increase in demand and product development, the more efficient and effective organizations were forced to improve their quality of product or services and operations. Numerous studies showed the positive relationship between from TQM practices with the operational performance 
of the organisation. However, there is no clear idea about the TQM practices in more accurate to the operational performance of the organisation. Specifically, the industries such as service and manufacturing have obtained the growth in their good performance this is because of their quality. Moreover, these are all the industries that has great impact on the technological growth and accordingly this growth would impact the quality of entire operational performance of industries, hence the best practices are necessary to make the industrial products as more quality. Considering this, the present paper empirically tests the relation of TQM practices on operational performance of both service and manufacturing industries.

\section{Literature review}

\section{Total Quality Management}

Quality is a huge component of the management in keeping the clients fulfilled. The quality of service and products are essential in almost all sectors, especially in service and manufacturing industries. Quality management idea has discovered wonderful criticality in associations and establishments and has changed to contemporary management approach in present age levels in twofold essentialness in deciding a suitable structure for essential prerequisites. Along these lines, the vital point is to embed quality exchange in the basicscheme of outlining the structure of an association (Prajogo and Sohal, 2006). The logic of TQM advanced mainly in the last three decades, incorporated a format for accomplishment through client fulfillment. TQM is recognized as a source of development, preference, and authoritative society (Irani et al., 2004). For instance, if the employee is supposed to be served low quality as a result, the client will be disappointed (Demirbag et al., 2006). TQM is a series of management practices relevant to the entire establishment and formatted to guarantee that the establishment continually fulfills or surpasses customer needs. Understanding this, some researchers conducted a study in the aspect of TQM practices for testing the effect on nonfinancial and financial performance. Such activities are role of the quality department, quality data and reporting, product service design, management leadership, employee relations, training, strategic planning, supplier quality management, process management, information technology and training, customer focus and people management (Claver and Tari, 2003; Demirbag et al., 2006; Flynn et al., 1995; Fotopoulos and Psomas, 2009; Kanji, 2002; Salaheldin, 2009; Turkyilmaz et al., 2010; Yusof and Aspinwall, 2000).

\section{The relationship between TQM activities and Operational performance}

There are numerous studies in past carried out the research in context of TQM implementation support and challenges for organisational performance specifically in operational area in more peculiar to both developed and developing countries (Babaita et al., 2011; Belay et al., 2011; Idris, 2011; Irfan et al., 2012; Jaafreh and Al-abedallat, 2012; Munizu, 2013). For instance, developed countries like Turkey study of Sadikoglu and Zehir (2010) examined the associations between TQM approaches and various functional dimensions and to scrutinize the arbitrating impacts of employee functioning and modernization on the correlation between TQM methods and organisation functioning. The research utilized a cross-sectional survey technique by survey questionnaire was sent to 500 ISO 9001:2000 approved companies chosen at random, in various sectors in the Marmara area in 
Int.J.Curr.Res.Aca.Rev.2016; 4(11): 75-86

Turkey in 2005 and 2006 and 373 functional questionnaires were collected. Findings of the research suggested that employee functioning and modernization are arbitrarily related to TQM approaches and company functioning.

In Spain, a study by De Cerio (2003) determined the association between the operational performance and implementation level of quality management practices in 50 Spain manufacturing sector. Hence study used survey method and carried out multiple regression analysis. The study result found out the association of quality management practices and operational performance.

While, developing countries like Tunisia, the relationship that exists between the quality management practices and their impact on performance was explored by Lakhal et al., (2006). Hence the study collected data from 133 Tunisia based companies. Their study is taken three critical quality management practices such as core, infrastructural and management. The results revealed that a positive relationship exists between organizational performance and quality management practices.

In Qatar, the study of Salaheldin (2009) examined whether TQM practices helped the growth of SMEs. Further this study analysed the critical success factors in the implementation of TQM in order to assess the operational performance and organizational performance. Hence, the study used the designed questionnaire, and it was distributed to 297 SMEs. The key findings found out such as substantial positive effect shown by the TQM implementation on both the operational and organizational performance. The results confirmed the significant relationship exists between the operational and organizational performance in SMEs.

In India, study like Seth and Tripathi (2005) studied TQM by itself; TPM by itself; both TQM and TPM in combination. Experimental study based on a survey, with a sample size of 108 production firms was done. The study recognized two groups of features that were vital for efficient execution of TQM as well as TPM: commonly essential features for every one of the methods like leadership, procedural management and strategic planning; and method-specific features like tool management and emphasis on customer contentment.

Nair (2006) examined the influence of TQM methods on functioning of a perfect background for concept expansion and improvement using meta-analysis methods. Firstly, the study approves functional inferences of accepting Quality Managementpractices and put forward a theorized association between QM methods and functioning. Secondly, the meta-analysis of association technique is employed to investigate the experimental study in Quality Management to decide the Quality Management method that is constructively connected to enhance functioning. The findings showed several theorized associations and ascertained the existence of arbitrating features in mostQuality Managementpractices such as functioning relationshipsimproving operational performance.

A comprehensive assessment framework was suggested by Shrivastava et al. (2006) after examining the need for establishing the linkages between the factors which affect TQM correlated with operational performance. The authors have designed a diagnostic instrument for testing in Indian 
industries which have implemented the TQM in the past decade. With the results from the analyzed data, a high, as well as weak linkage, is established which helps to improve the TQM, which is customized as per Indian scenario. This study contributed in providing feedback for managing as well as improving the TQM programs for efficient organizational performance.

It can hence be concluded here that globally and national level, many studies evaluated the effect of TQM on organisational performance, of which all have proved that TQM is useful. The drawback, however, is that it speaks of these effects only on the organisation but does not segregate into the top, middle or lower levels of the organisation.

\section{Research design}

\section{Data collection}

The data has been collected by using primary data collection. In primary data collection, the study used survey type of data collection among 300 participants from 50 service and manufacturing industries in India. The questionnaire might be simple to implement; however, the result of the process is likely to be more efficient (Zikmund, 2003). The sole purpose of the research is to identify the relation of TQM practices on operational performance of Indian manufacturing and service firms. Hence the questionnaire was prepared to attain the objectives.

\section{Measures}

The survey questionnaire consists of closedended questions. In order to determine the research framework, it requires generating questions involving age, occupation, and gender to achieve the prime objective in the quantitative component involving the questionnaire approach. In this survey, multiple TQM factors are generated such as leadership, process management, employee management, continuous improvement, and customer focus. 5-point Likert scale is included in the questionnaire to convey the attributes of the participants effectively towards the organization. The respondents require answering the Likert Scale questions through a range of solutions, which begins with Strongly Agree to conclude at Strongly Disagree. As per the suggestion of HewittDundas (2004), there are chances of accruing benefits in the questionnaire approach through adopting the Likert Scale, due to the potential to make a difference among various levels of attitudes. After data collection, a pilot study was done. Once the pilot analysis was completed, the main study was carried out.

\section{Data analysis}

Table 1 shows the mean comparison between manufacturing and service industries based on the factors of TQM practices. From the significance value ( $>0.05$ ), there is no statistically significant difference between these two industries based on the response in relation to TQM practices. In addition, all these factors have the mean value $(>3.5)$ around 4.It indicates that majority of the respondents are agreed all the dimensions of TQM practices.

Table 2 shows the mean comparison between manufacturing and service industries based on the factor of operational performance. From the significance value ( $p>0.05)$, there is no statistically significant difference between these two industries based on the response about operational performance. In addition, these factors have the mean value (>3.5) around 4.It indicates 
that majority of the respondents are agreed with operational performance.

Table 3 presents the correlation analysis between the dimensions of TQM practices, quality performance, operational performance and business performance. Overall all these factors are a positively linear relationship with each other. This means that as one variable increase in value, and then another variable also increases in value. The amount of relationship value ranges from 0.322 to 0.993 .

Table 4 reveals the multiple regression analysis. In the manufacturing industry, the beta coefficient of the regression of operational performance on leadership (beta=0.990, $\mathrm{t}=47.127, \quad \mathrm{p}<0.001$ ) and Information and Analysis (beta $=0.025$, $\mathrm{t}=2.144, \mathrm{p}<0.05)$ is statistically significant. Since the significance is less than the alpha of 0.05 values, the null hypothesis is accepted and hence there is a support of the hypothesis. Independent variables together accounted for $99 \%$ of the variance ( $R$ square) which indicates that operational performance is a more significant predictor of Leadership and Information and Analysis.

In the service industry, the beta coefficient of the regression of operational performance on leadership $\quad($ beta $=1.022, t=71.595$, $\mathrm{p}<0.001)$ is statistically significant. Since the significance is less than the alpha of 0.05 values, the null hypothesis is accepted and hence there is a support of the hypothesis. Independent variables together accounted for $98 \%$ of the variance ( $\mathrm{R}$ square) which indicates that operational performance is a more significant predictor of Leadership.

Table 5 presents the linear regression analysis. In the manufacturing industry, the beta coefficient of the regression of operational performance on quality performance $($ beta $=0.898, \mathrm{t}=30.484, \mathrm{p}<0.01$ ) is statistically significant. Since the significance is less than the alpha of 0.05 values, the null hypothesis is accepted and hence there is a support of the hypothesis. Independent variables together accounted for $89 \%$ of the variance ( $\mathrm{R}$ square) which indicates that operational performance is a more significant predictor of quality performance.

In the service industry, the beta coefficient of the regression of operational performance on quality performance (beta $=0.807$, $\mathrm{t}=29.288, \mathrm{p}<0.01)$ is statistically significant. Since the significance is less than the alpha of 0.05 values, the null hypothesis is rejected and hence there is a support of the hypothesis. Independent variables together accounted for $82 \%$ of the variance ( $R$ square) which indicates that operational performance is a more significant predictor of quality performance.

Upon satisfaction of reliability and validity of individual constructs as well as the overall supply chain management practices model (Fig.1), the study proceeded to determine the fitness of the overall measurement model based on model fit indices generated as a part of AMOS output. Model fit is assessedon the basis of CMIN/df, P-value, Comparative Fit Index (CFI), Goodness of Fit Index (GFI), Adjusted Goodness of Fit Index (AGFI), Root Mean Square Error of Approximation (RMSEA) and P close. Model fit indices for supply chain management practices and product quality constructs were calculated, and the results have been indicated in Table 6.

\section{Discussion and Conclusion}

TQM is considered to be the quality oriented approach and effects on operational performance were viewed by various past 
studies. The fundamental elements of TQM are given by the American Society for Quality Control are policy, planning, and administration; product design and design change control; control of purchased material;production quality control; user contact and field performance;corrective action; andemployee selection, training, and motivation 2015).

Table.1 Comparison between manufacturing and service industries based on the dimensions of TQM practices

\begin{tabular}{|c|c|c|c|c|}
\hline \multirow{3}{*}{ Variables } & \multicolumn{2}{|l|}{ Industry type } & \multirow{3}{*}{ t-value } & \multirow{3}{*}{ p-value } \\
\hline & Manufacturing & Service & & \\
\hline & \multicolumn{2}{|l|}{ Mean \pm SD } & & \\
\hline Leadership & $4.28 \pm 0.77$ & $4.39 \pm 0.58$ & -1.470 & 0.143 \\
\hline Strategic and Planning & $4.07 \pm 0.94$ & $4.15 \pm 0.97$ & -0.675 & 0.500 \\
\hline Customer Focus & $3.81 \pm 1.15$ & $3.85 \pm 1.14$ & -0.269 & 0.788 \\
\hline Information and Analysis & $3.64 \pm 1.23$ & $3.71 \pm 1.28$ & -0.438 & 0.662 \\
\hline People Management & $3.57 \pm 1.22$ & $3.63 \pm 1.17$ & -0.365 & 0.715 \\
\hline Process Management & $3.92 \pm 1.17$ & $3.87 \pm 1.23$ & 0.387 & 0.699 \\
\hline
\end{tabular}

Table.2 Comparison between manufacturing and service industries based on the operational performance

\begin{tabular}{|l|l|l|l|l|}
\hline \multirow{2}{*}{ Variables } & \multicolumn{2}{|l|}{ Industry type } & \multirow{3}{*}{ t-value } & \multirow{2}{*}{ p-value } \\
\cline { 2 - 3 } & Manufacturing & Service & & \\
\cline { 2 - 3 } Operational Performance & Mean \pm SD & $4.41 \pm 0.60$ & -1.454 & 0.147 \\
\hline
\end{tabular}

Table.3 Correlation between the dimensions of TQM practices, Quality performance, Operational performance and Business performance

\begin{tabular}{|c|c|c|c|c|c|c|c|c|c|}
\hline & V1 & $\mathrm{V} 2$ & V3 & V4 & V5 & V6 & V7 & V8 & V9 \\
\hline V1 & 1 & $.749 * *$ & $.655^{* *}$ & $.574 * *$ & $.357 * *$ & $.369 * *$ & $.918^{* *}$ & $.993 * *$ & $.749 * *$ \\
\hline $\mathrm{V} 2$ & & 1 & $.767 * *$ & $637 * *$ & $369 * *$ & $387 * *$ & $.791 * *$ & $.753 * *$ & $.970 * *$ \\
\hline V3 & & & 1 & $.805 * *$ & $415 * *$ & $322 * *$ & $.829 * *$ & $.658 * *$ & $.774 * *$ \\
\hline V4 & & & & 1 & $.556 * *$ & $456 * *$ & $688 * *$ & $.582 * *$ & $.696 * *$ \\
\hline V5 & & & & & 1 & $739 * *$ & $.372 * *$ & $.350 * *$ & $.541 * *$ \\
\hline V6 & & & & & & 1 & $.343 * *$ & $.367 * *$ & $.505 * *$ \\
\hline V7 & & & & & & & 1 & $.926 * *$ & $.790 * *$ \\
\hline V8 & & & & & & & & 1 & $.750 * *$ \\
\hline V9 & & & & & & & & & 1 \\
\hline
\end{tabular}

**. Correlation is significant at the 0.01 level (2-tailed).

Where V1= Leadership, V2= Strategic and Planning, V3= Customer Focus, V4= Information and Analysis, V5= People Management, V6= Process Management, V7= Quality Performance, V8= Operational Performance, V9= Business Performance. 
Int.J.Curr.Res.Aca.Rev.2016; 4(11): 75-86

Table.4 Association between dimensions of TQM practices and operational performance

\begin{tabular}{|c|c|c|c|c|c|c|c|}
\hline \multirow[b]{2}{*}{ Industry type } & & \multicolumn{2}{|c|}{$\begin{array}{l}\text { Unstandardized } \\
\text { Coefficients }\end{array}$} & \multirow{2}{*}{$\begin{array}{l}\text { Adjusted } \\
\text { R-square }\end{array}$} & \multirow{2}{*}{$\begin{array}{l}\text { F- } \\
\text { change }\end{array}$} & \multirow{2}{*}{$\begin{array}{l}\text { t- } \\
\text { value }\end{array}$} & \multirow[t]{2}{*}{ p-value } \\
\hline & & Beta & SE & & & & \\
\hline \multirow{7}{*}{ Manufacturing } & (Constant) & -0.051 & 0.046 & \multirow{7}{*}{0.989} & \multirow{7}{*}{1689.938} & -1.124 & 0.264 \\
\hline & Leadership & 0.990 & 0.021 & & & 47.127 & $0.000 * *$ \\
\hline & $\begin{array}{l}\text { Strategic and } \\
\text { Planning }\end{array}$ & 0.026 & 0.018 & & & 1.417 & 0.159 \\
\hline & $\begin{array}{l}\text { Customer } \\
\text { Focus }\end{array}$ & -0.012 & 0.015 & & & -0.786 & 0.433 \\
\hline & $\begin{array}{l}\text { Information } \\
\text { and Analysis }\end{array}$ & 0.025 & 0.012 & & & 2.144 & $0.034^{*}$ \\
\hline & $\begin{array}{l}\text { People } \\
\text { Management }\end{array}$ & -0.021 & 0.012 & & & -1.830 & 0.070 \\
\hline & $\begin{array}{l}\text { Process } \\
\text { Management }\end{array}$ & 0.007 & 0.012 & & & 0.582 & 0.562 \\
\hline \multirow{7}{*}{ Service } & (Constant) & -0.130 & 0.048 & \multirow{7}{*}{0.983} & \multirow{7}{*}{1741.684} & -2.715 & 0.007 \\
\hline & Leadership & 1.022 & 0.014 & & & 71.595 & $0.000 * *$ \\
\hline & $\begin{array}{l}\text { Strategic and } \\
\text { Planning }\end{array}$ & 0.008 & 0.011 & & & 0.791 & 0.430 \\
\hline & $\begin{array}{l}\text { Customer } \\
\text { Focus }\end{array}$ & -0.001 & 0.010 & & & -0.079 & 0.937 \\
\hline & $\begin{array}{l}\text { Information } \\
\text { and Analysis }\end{array}$ & 0.008 & 0.009 & & & 0.919 & 0.359 \\
\hline & $\begin{array}{l}\text { People } \\
\text { Management }\end{array}$ & -0.008 & 0.008 & & & -1.037 & 0.301 \\
\hline & $\begin{array}{l}\text { Process } \\
\text { Management }\end{array}$ & 0.004 & 0.007 & & & 0.542 & 0.589 \\
\hline
\end{tabular}

Dependent Variable: Operational performance $* * p<0.01,{ }^{*} \mathrm{p}<0.05$

Table.5 Association between dimensions of quality performance and operational performance

\begin{tabular}{|c|c|c|c|c|c|c|c|}
\hline \multirow[t]{2}{*}{ Industry type } & & \multicolumn{2}{|c|}{$\begin{array}{l}\text { Unstandardized } \\
\text { Coefficients }\end{array}$} & \multirow{2}{*}{$\begin{array}{l}\text { Adjusted } \\
\text { R- } \\
\text { square }\end{array}$} & \multirow{2}{*}{$\begin{array}{l}\text { F- } \\
\text { change }\end{array}$} & \multirow{2}{*}{$\begin{array}{l}\text { t- } \\
\text { value }\end{array}$} & \multirow[t]{2}{*}{ p-value } \\
\hline & & Beta & SE & & & & \\
\hline \multirow[b]{2}{*}{ Manufacturing } & (Constant) & 0.557 & 0.125 & \multirow[b]{2}{*}{0.892} & \multirow[b]{2}{*}{929.280} & 4.457 & 0.000 \\
\hline & $\begin{array}{l}\text { Quality } \\
\text { Performance }\end{array}$ & 0.898 & 0.029 & & & 30.484 & $0.000 * *$ \\
\hline \multirow[b]{2}{*}{ Service } & (Constant) & 0.961 & 0.119 & \multirow[b]{2}{*}{0.822} & \multirow[b]{2}{*}{857.774} & 8.063 & 0.000 \\
\hline & $\begin{array}{l}\text { Quality } \\
\text { Performance }\end{array}$ & 0.807 & 0.028 & & & 29.288 & $0.000 * *$ \\
\hline
\end{tabular}

Dependent Variable: Operational Performance**p<0.01. 
Int.J.Curr.Res.Aca.Rev.2016; 4(11): 75-86

Table.6 Model fit indices for full order model constructs of total quality management practices (TQM) and Quality performance

\begin{tabular}{|l|l|l|}
\hline Variable & Value & Suggested value \\
\hline Chi-square value & 135.417 & \\
\hline Degrees of freedom $(\mathrm{df})$ & 64 & \\
\hline P value & 0.000 & P-value $>0.05$ (Hair et al., 2006) \\
\hline GFI & 0.943 & $>0.90$ (Hair et al., 2006) \\
\hline AGFI & 0.906 & $>0.90($ Daire et al., 2008) \\
\hline CFI & 0.988 & $>0.90($ Hu and Bentler, 1999) \\
\hline RMR & 0.026 & $<0.08$ (Hair et al., 2006) \\
\hline RMSEA & 0.061 & $<0.08$ (Hair et al., 2006) \\
\hline
\end{tabular}

Fig.1 Second-order model (Operational Performance as dependent variable)

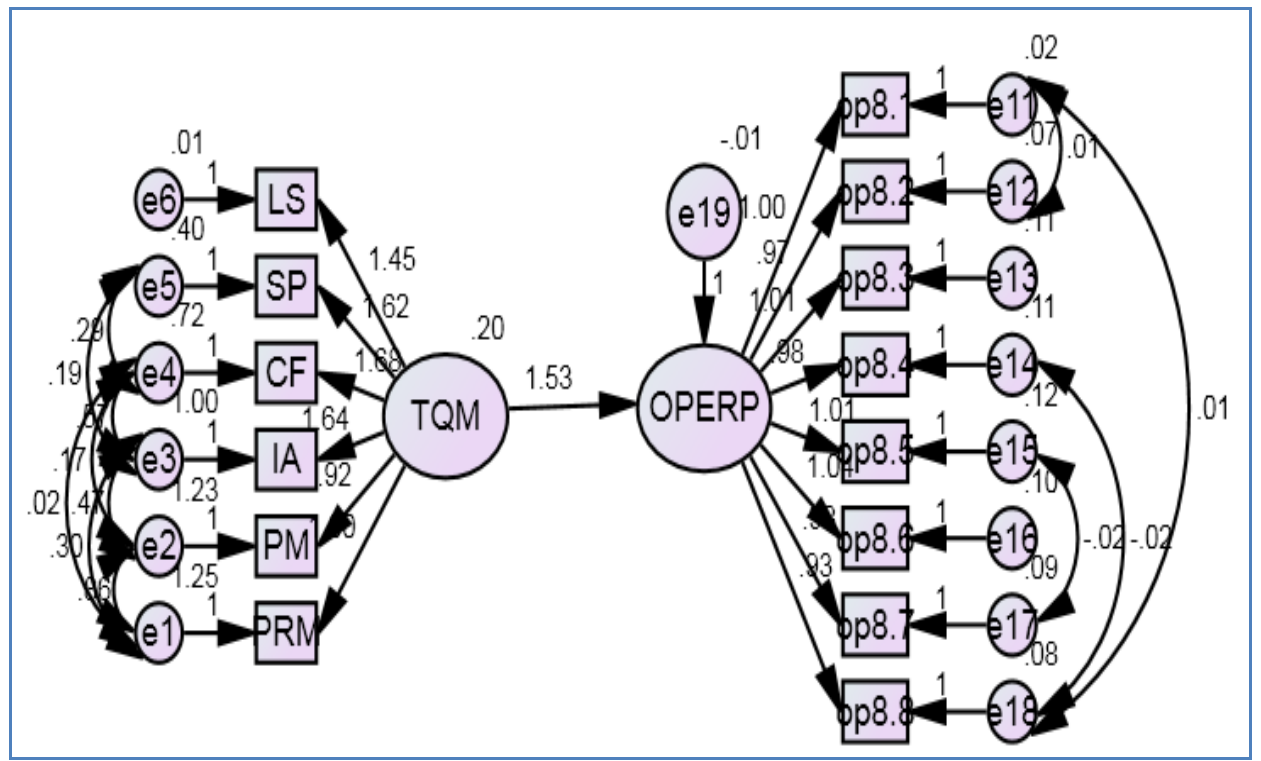

Studies of TQM practices are related to the performances of the manufacturing unit in general (Chenhall, 1997; Mann and Kehoe, 1994), and in regards, to quality was described by (Fuentes et al., 2006; Lee et al., 2003; Prajogo and Hong, 2008). In addition to this, some other elements determined by various authors with respect to employee satisfaction (Fuentes et al., 2006; Sadikoglu and Zehir, 2010), novelty (Prajogo and Hong, 2008; Sadikoglu and Zehir, 2010; Santos-Vijande and AlvarezGonzalez, 2007), customer satisfaction (Choi and Eboch, 1998; Das et al., 2000;
Fuentes et al., 2006), competitive advantage (Agus and Sagir, 2001; Brah et al., 2002), market share (Mohrman et al., 1995), finance (Easton and Jarrell, 1998; Fuentes et al., 2006; Tena et al., 2001).

On the other hand, it supports the total performance of the firm (Brah et al., 2002; De Cerio, 2003; Douglas and Judge, 2001; Kaynak, 2003; Sadikoglu and Zehir, 2010; Sharma, 2006). In this study,results reveals that the operational performance views Leadership, Strategic and Planning, Customer Focus, Information and Analysis, 
Int.J.Curr.Res.Aca.Rev.2016; 4(11): 75-86

People Management and Quality Performance are statistically significant. In line with several previous studies of Zhao et al. (2004), Lai and Cheng (2003) and Witt and Muhlemann (1994) found out the operational performance and effect of TQM practices in different sectors. In this view, the present study result applies to manufacturing and service sector. Likewise, Sila and Ebrahimpour (2005) showed the organisational performance in terms of implementing TQM practices based on the customer focus, leadership, process management, strategic planning, supplier management, people management and information and analysis. From the analysis and reviews of previous studies, it is observed that both management and service industries should consider the practices of TQM variables in enhancing product quality performance such as leadership, process management, customer focus, and strategic planning in product quality. There are numerous papers viewed the impact of TQM on reliability. However, there is not much literature on the relation of TQM on the performance and durability. Such research would help in developing a roadmap for the firms in implementing the performance and durability in different sectors also identify the possible pros and cons associated with it. Moreover, most of the previous literature focused the business and quality performance in manufacturing and service industries in India, to our knowledge, with respect to operational is restricted. Hence the study providesan excellent scope for future researchers.

\section{References}

Agus, A. \& Sagir, R.M. 2001. "The structural relationships between total quality management, competitive advantage and bottom line financial performance: An empirical study of Malaysian manufacturing companies",
Total Quality Management, Vol. 12 No. 7-8, pp 1018-1024.

Babaita, I.S., Abdulraheem, A. \&Salam, M.O. 2011. "Total Quality Management and Its Effect on Performance of Private Firms in Kwara State, Nigeria Abstract":, Interdisciplinary Review of Economics and Management, Vol. 1 No. 2, pp $37-42$.

Belay, A., Helo, P. \&Takala, J. 2011. "Effects of Quality Management Practices and Concurrent Engineering in Business Performance", Int. J. Bus. Manage, Vol. 6 No. 3, pp 45-62.

Brah, S.A., Tee, S.S.L. \&Madhu Rao, B. 2002. "Relationship between TQM and performance of Singapore companies", Int. J. Quality \& Reliability Management, Vol. 19 No. 4, pp 356-379.

De Cerio, J.M. 2003. "Quality management practices and operational performance: Empirical evidence for Spanish industry", Int. J. Production Res., Vol. 41 No. 12, pp 2763-2786.

Chenhall, R.H. 1997. "Reliance on manufacturing performance measures, total quality management and organizational performance", Management Accounting Res., Vol. 8 No. 2, pp 187-206.

Choi, T.Y. \&Eboch, K. 1998. "The TQM Paradox: Relations among TQM practices, plant performance, and customer satisfaction", J. Operations Management, Vol. 17 No. 1, pp 5975.

Claver, E. and Tari, J. 2003. "Critical factors and results of quality management: an empirical study", Total Quality Management \& Business Excellence, Vol. 14 No. 1, pp 91-118.

Daire, H., Joseph, C. \&Michael, R. 2008. "Structural Equation Modeling: Guidelines for Determining Model 
Fit”, Electronic J. Business Res. Methods, Vol. 6 No. 1, pp 53-60.

Das, A., Handfield, R.B., Calantone, R.J. \&Ghosh, S. 2000. "A Contingent View of Quality Management-The Impact of International Competition on Quality", Decision Sci., Vol. 31 No. 3, pp 649-690.

Demirbag, M., Tatoglu, E., Tekinkus, M. \&Zaim, S. 2006. "An analysis of the relationship between TQM implementation and organizational performance: Evidence from Turkish SMEs", J. Manufacturing Technol. Management, Vol. 17 No. 6, pp 82947.

Douglas, T.J. \&Judge, W.Q. 2001. "Total Quality Management Implementation and Competitive Advantage: The Role of Structural Control and Exploration", Academy of Management J., Vol. 44 No. 1, pp 158-169.

Easton, G.S. \&Jarrell, S.L. 1998. "The Effects of Total Quality Management on Corporate Performance: An Empirical Investigation", The $J$. Business, Vol. 71 No. 2, pp 253-307.

Flynn, B.B., Schroeder, R.G. \&Sakakibara, S. 1995. "The Impact of Quality Management Practices on Performance and Competitive Advantage", Decision Sciences, Vol. 26 No. 5, pp 659-691.

Fotopoulos, C.B. and Psomas, E.L. 2009. "The impact of soft and hard TQM elements on quality management results", Int. J. Quality \& Reliability Management, Vol. 26 No. 2, pp 15063.

Fuentes, M.M.F., Montes, F.J.L. \&Fernández, L.M.M. 2006. "Total Quality Management, strategic orientation and organizational performance: the case of Spanish companies", Total Quality
Management \& Business Excellence, Vol. 17 No. 3, pp 303-323.

Hair, J., Joseph, Bush, R. \&Ortinau, D. 2006. Marketing Research, 3rd ed., McGrawHill/Irwin, London.

Hewitt-Dundas, N. 2004. "The adoption of advanced manufacturing technology and innovations strategy in small firms", Int. J. Innovation and Technology Management, Vol. 1 No. 1, pp 17-36.

$\mathrm{Hu}$, L. and Bentler, P.M. 1999. "Cutoff Criteria For Fit Indexes In Covariance Structure Analysis: Conventional Criteria Versus New Alternatives", Structural Equation Modeling: A Multidisciplinary J., Vol. 6 No. 1, pp $1-55$.

Idris, F. 2011. "Total Quality Management ( TQM ) And Sustainable Company Performances: Examining The Relationship In Malaysian", Int. J. Business and Society, Vol. 12 No. 1, pp 31-52.

INC. 2015. "Total Quality Management (TQM)", available at: http://www.inc.com/encyclopedia/total -quality-management-tqm.html (accessed 23 February 2015).

Irani, Z., Beskese, A. \&Love, P.E.D. 2004. "Total quality management and corporate culture: Constructs of organizational excellence", Technovation, Vol. 24, pp 643-50.

Irfan, S.M., Ijaz, A., Kee, D.M.H. \&Awan, M. 2012. "Improving Operational Performance of Public Hospital in Pakistan: A TQM Based Approach", World Appl. Sci. J., Vol. 19 No. 6, pp 904-913.

Jaafreh, A.B. \&Al-abedallat, A.Z. 2012. "The Effect of Quality Management Practices on Organizational Performance in Jordan: An Empirical Study", Int. J. Financial Res., Vol. 4 No. 1, pp 93-109. 
Kanji, G.. 2002. Measuring Business Excellence, Routledge, Advances in Management and Business Studies.

Kaynak, H. 2003. "The relationship between total quality management and their effects on firm performance", Journal of Operations Management, Vol. 21, pp 405-35.

Lai, K. \&Cheng, T.C.E. 2003. "Initiatives and outcomes of quality management implementation across industries", Omega, Vol. 31 No. 2, pp 141-154.

Lakhal, L., Pasin, F. \&Limam, M. 2006. "Quality management practices and their impact on performance", Int. J. Quality \& Reliability Management, Vol. 23, pp 625-646.

Lee, J.H., Garza-Reyes, J.A., Kumar, V., Rocha-Lona, L. \&Mishra, N. 2013. “A Comparative Study of the Implementation Status of Lean Six Sigma in South Korea and the UK", Lecture Notes in Mechanical Engineering, Switzerland, pp 14891502.

Lee, S.M., Rho, B.-H. \&Lee, S.-G. 2003. "Impact of Malcolm Baldrige National Quality Award criteria on organizational quality performance", Int. J. Production Res., Vol. 41 No. 9, pp 2003-2020.

Mann, R. \&Kehoe, D. 1994. “An Evaluation of the Effects of Quality Improvement Activities on Business Performance", Int. J. Quality \& Reliability Management, Vol. 11 No. 4, pp 2944.

Mohrman, S.A., Tenkasi, R. V., Lawler, E.E. \&Ledford, G.E. 1995. "Total quality management: practice and outcomes in the largest US firms", Employee Relations, Vol. 17 No. 3, pp 26-41.

Munizu, M. 2013. “Total Quality Management ( TQM ) Practices toward Product Quality Performance :
Case at Food and Beverage Industry in Makassar , Indonesia", IOSR Journal of Business and Management (IOSRJBM, Vol. 9 No. 2, pp 55-61.

Nair, A. 2006. "Meta-Analysis of the Relationship between Quality Management Practices and Firm Performance - Implications for Quality Management Theory Development", $J$. Operations Management, Vol. 24, pp 948-975.

Prajogo, D.I. \&Hong, S.W. 2008. "The effect of TQM on performance in R\&D environments: A perspective from South Korean firms", Technovation, Vol. 28 No. 12, pp 855-863.

Prajogo, I.D. \&Sohal, S.A. 2006. "The relationship between organization strategy, total quality management (TQM. and organization performance the mediating role of TQM", $J$. Operational Research, Vol. 168, pp 35-50.

Sadikoglu, E. \&Zehir, C. 2010. "Investigating the effects of innovation and employee performance on the relationship between total quality management practices and firm performance: An empirical study of Turkish firms", Int. J. Production Economics, Vol. 127 No. 1, pp 13-26.

Salaheldin, I. 2009. "Critical success factors for TQM implementation and their impact on performance of SMEs", Int. J. Productivity and Performance Management, Vol. 58 No. 3.

Santos-Vijande, M.L. \&Alvarez-Gonzalez, L.I. 2007. "TQM and Firms Performance: An EFQM Excellence Model Research Based Survey", Int. J. Business Sci. Appl. Management, Vol. 2 No. 2, pp 21-41.

Seth, D. \&Tripathi, D. 2005. "Relationship between TQM and TPM implementation and business 
Int.J.Curr.Res.Aca.Rev.2016; 4(11): 75-86

performance of manufacturing industry in an Indian context", Int. J. Quality \& Reliability Management, Vol. 22 No. 3, pp 256-277.

Sharma, B. 2006. "Quality Management Dimensions, Contextual Factors and Performance: An Empirical Investigation", Total Quality Management \& Business Excellence, Vol. 17 No. 9, pp 1231-1244.

Shrivastava, R.L., Mohanty, R.P. \&Lakhe, R.R. 2006. "Linkages between total quality management and organisational performance: an empirical study for Indian industry", Production Planning \& Control, Vol. 17 No. 1, pp 13-30.

Sila, I. \&Ebrahimpour, M. 2005. "Critical linkages among TQM factors and business results", Int. J. Operations \& Production Management, Vol. 25 No. 11, pp 1123-1155.

Tena, A.B.E., Llusar, J.C.B. and Puig, V.R. 2001. "Measuring the relationship between total quality management and sustainable competitive advantage: A resource-based view", Total Quality Management, Vol. 12 No. 7-8, pp
932-938.

Turkyilmaz, A., Tatoglu, E., Zaim, S. and Ozkan, C. 2010. "TQM practices and business performance in SMEs", in Esposito, V. V., W., C.W., Henseler, J. and Wang, H. Eds.. Handbook of Partial Least Squares, 1st ed., Springer-Verlag, pp 605-621.

Witt, C. \&Muhlemann, A. 1994. "The implementation of total quality management in tourism: some guidelines", Tourism Management, Vol. 15 No. 6, pp 416-424.

Yusof, S.M. \&Aspinwall, E. 2000. "A conceptual framework for TQM implementation for SMEs", The TQM Magazine, Vol. 12 No. 1, pp 31-37.

Zhao, X., Yeung, A.C.L. \&Lee, T.S. 2004. "Quality management and organizational context in selected service industries of China", $J$. Operations Management, Vol. 22 No. 6, pp 575-587.

Zikmund, W.G. 2003. Business Research Methods, book, Thomson Learning, South-Western, USA.

\section{How to cite this article:}

Vasantharayalu. 2016. Impact of TQM Practices on Operational Performance of Firms in India - An Empirical Study. Int.J.Curr.Res.Aca.Rev.4(11): 75-86. doi: http://dx.doi.org/10.20546/ijcrar.2016.411.002 